\title{
SOCIAL CLASS IN BRITISH SOCIETY IN JANE AUSTEN'S PRIDE AND PREJUDICE
}

\author{
* Mira Andrea Putri \\ **Syamsul Bahri \\ ***Rita Suswati
}

\begin{abstract}
This study deals with social class in British society in Jane Austen's Pride and Prejudice. The objectives of this study were to find out the impacts of social class toward british society based on the novel Pride and Prejudice written by Jane Austen and to describe social class reflected toward british society in that novel. The study was conducted by using descriptive qualitative method. The data of this research were dialogues and narration in Pride and Prejudice novel. The analysis of this study was based on Marxist's concept (1995:25). The findings of this study were (1) two impacts of social class toward british society found in Pride and Prejudice novel, they were pride and prejudice (2) three types of social classes which were reflected, such as power, wealth, and status.
\end{abstract}




\section{INTRODUCTION}

Literature, as a part of art, gives pleasure, contentment, and some experiences for people who are interest in it. It appreciates more about life, because the problem of human life, society and the environment can be seen through literary works. In other words, literature gives the reader experiences through the way of artistic form. This is why literature is a vital record of what human have seen in life, what they have experienced about it, what they have thought and felt about those aspects of it which have the most immediate and enduring interest for all of the readers.

One of the literary works is a novel. It rises as something that people may understand with the same principle in daily life. That is why novel as a literary work reflects the social reality which is seen from social aspect,economic aspect, political aspect, science and technology aspect, cultural aspect, and religious aspect.

There are some themes of novels. One of them is social class. It is one of social problems because it makes some chaos around human's life. Social class comprises relationships to the system of ownership of physical and cultural capital, the structure of authority at work and in society, and the content and process of one's work activity. It means that social class can be defined as a large social group that shares common socio-economic characteristics (wealth, status, and power) and similar lifestyles. 
In the novel Pride and Prejudice, Jane Austen wrote about social class. It describes how income, family, and living circumstances, all contributed to mark out social class. In the novel Pride and Prejudice, Austen described that the importance of marriage has important role in social rank because it showed many aspects of marriage and demonstrating how people can make the most of their life regardless of the circumstances(Frederick, 2011:34). Austen throughout her novel described the societal state of 19th century in England with awareness of the social issues that affect her society, where marriage were based on economical reasons and social background rather than capability and love. She wrote this novel to describe the effects of social class on marriage, and marriage on class. With great irony and satirist, Jane showed how people were influenced by social rank and wealth, and marriage was the status that all women strive to achieve (Saidin, 2013:7). The author satirized the convention of marriage in her novel placed on an acquisitive society, demonstrating that the mere personally liking, wealth, and class factors could produce only misery, shame, unhappiness and isolation.

The novelPride and Prejudice describes a lot of emotions between the two protagonists, Darcy and Elizabeth, in the disordered 19th century. Darcy was too proud of himself. He couldn't trust others and try to find the shortcomings of others. However, Elizabeth always put her prejudice on those who she teased. They argued with, criticized and even slanted each other. That they kept commenting on each other unexpectly attracted these two young people to put more attention on him or her. In the end, they found out that they had a lot of 
misunderstandings. They broke those social class and solve all the misunderstandings together.

Issues of social class are very interesting to be discussed not only in the novel Pride and Prejudice, but alsoother novels. Rahayu (2013) found the operationofsocialclassin Igbotribesociety depictedinAchebe'snovel.Thistopic appearedastheresponseofbiased classsociety presentedby thenovel.She found that social injusticedepicted asfollows; someonewho hasmanyhugebarns ofyams, title,andwarrior become the ruling class and get great respect by the society. While, women area the bottom of the society, and there is $o s u$, known as social outcasts, who have social status as slave. Theydonothaveanysocialstatus. That is why the issue of social class is very interesting to be discussed because it affects a person's personality.

Considering to the previous explanations, the aim of this study wereto find out the impacts of social class and to describe the reflection of social classes toward british society based on the novel Pride and Prejudice written by Jane Austen.Pride and prejudice was chosen because it was a popular novel in world, the story charts the emotional development of the protagonist, Elizabeth Bennet, who learns the error of making hasty judgments and comes to appreciate the difference between the superficial and the essential. The comedy of the writing lies in the depiction of manners, education, marriage, and money during the British Regency period. 


\section{REVIEW OF LITERATURE}

Literature is an interesting subject to be discussed. It is created by authors to share ideas and thoughts that are expressed in the literary work. Literature, like other arts, is essentially an imaginative act, that is, an act of thewriter's imagination in selecting, ordering, and interpreting life-experiences. In the case of literature, words are the medium of expression and it makes little differences whether those words are recorded in the living memory of a people or by some mechanical means such as writing, sound recording, etc. (Taylor 1981:1)

The relation between literature and ideas can be described in different ways and literary analysis. Usually it is required in the study of literature and its importance to human life. Through the analysis, the readers or investigators can deeply understand the values, beliefs, knowledge, and the symbols that are represented in the story.

One of literary work is a novel. Novel is defined as fiction or story that may be imaginary. Barnhart (2001:865) says that the novel is fictitious prose narrative of considerable length which portrays characters and actions representatives of real life in a plot of more or less intricate.In social life, people are demanded to live in integrated individuals where each individual delivers different characteristics. These differences finally construct a problem within the social life, especially economic problems. Economic problem has been classic problem that cannot be avoided in modern life, thus people are categorized by their capability in economic status or class. 
Social Class can be defines as involving grouping people together and according them status within society to whom the group they belong to. It means that social class describes that stratification system. Barbusse and Glaymann, (2004:11) state that social class is a stratification system that divides a society into a hierarchy of social positions. It means that a particular social position within a class stratification system (lower class, working class, middle class). That is why social class can be called as a large social group sharing common socio-economic characteristics (wealth, status, power) and similar lifestyles.Marxist concept of class may be particularly suited to the distinctively Marxist question about potential emancipator transformations, is it still sociologically useful if one rejects that question (1995:25).

\section{RESEARCH METHODOLOGY}

\section{Methodology}

This study was conducted by using a descriptive qualitative method. Fraenkel and Wallen (1993: 23) state that descriptive method was method used to explain, analyze, and classify, something through various techniques, survey, interview, questionnaire, and test. In addition, Fraenkel and Wallen (1993:380) also explained about qualitative research. Qualitative research was defined as "a research study that investigates the quality of relationships, activities, situations or materials." Qualitative methods used descriptions and categories (words), for examples, open ended interviews, naturalistic observation, and document analysis. The writer analyzed the data one by one or detail. 
This studydescribed about social class and impacts for human's life which taken from Jane Austen's novel Pride and Prejudice.

\section{Data Analysis}

In analyzing the data the researcher used theory proposed by Marxist's concept(1995:25). In displaying data, the researcher described data by identified the data to find out the social class through dialogues and narration which were contained of how social class was described in the novel. Then, classified the data into the types of social impacts and how social class reflected.Analyzed the data based on Marxist's concept(1995:25) and last concluded the data found toward social class in btirish society to describedthe impacts of social class and the reflection of social class. It made an interpretation based on the finding from the data sheet. The result was the limited interpretation by the writer herself. It wasused to describe all of the data so that it would become clearly.

\section{DATA ANALYSIS AND RESEARCH FINDINGS}

From the impacts of social class toward british society in pride and prejudice, they were found Pride and Prejudice. And as a result from the reflection of social class toward britih society in pride and prejudice, they were Power, Status, Wealth. 
1. Impacts of social class Found in Pride and Prejudice novel:

a. Pride

Pride means a feeling or deep pleasure or satisfaction derived from power's own achievement, the achievement of those with whom one was closely associated or from qualities or possessions that were widely admired. The example of Pride was : Character: Mr.Darcy“She is tolerable, but not handsome enough to tempt me; I am in no humour at present to give consequence to young ladies who are slighted by other men." It means, Mr.Darcy was an intelligent and for the right gentleman.Healways had atendency to judge too hastily and harshly, and his high birth and wealthy make him overly proud and overly conscious of his social status. At that time he was reject to had a dance with Elizabeth. HedespisestheBennetsasvulgarandbeneathhim.

\section{b. Prejudice}

Prejudice was an effective feeling towards a person or group member based solely on their group membership. It refers to preconceived, usually unfavorable, feelings towards people or a person because of their social class. The example of $\quad$ Prejudice was: Character: Elizabeth "AndIhadnotknownyouamonthbeforeIfeltthatyouwerethe lastmanintheworldwhomIhadeverbeprevailedontomarry." it described that Elizabethheartilydislikeshimandhis a loofmanner andclass-basedpride. Prejudice also refers to unfounded beliefs and it may include any unreasonable attitude that was usually resistant to rational influence. 
ElizabethhadintensiveprejudiceagainstDarcyatfirst,shegraduallylost herjudgmentandcouldnotjudgewhotrulylovedher.

2. Social Class is Reflected through Power, Wealth, and Status

\section{a.Power}

Power was the ability to influence others to believe, behave, or to value as those in desire them to or to strengthen, validate, or confirm present beliefs, behaviors, or values. In this novel, the difference between the economic privilege of middle-class women and upper - class men give inequality of women and men. There were connection between money and power. They were conscious of having power to choose and they were fond of dwelling on it, of impressing it upon wrote a letter. The example of power was: Character: Mr.Darcy "No humor at present to give consequence to young ladies who are slighted by other men." at the first ball Mr.Darcy would not dance with Elizabeth because his power. Darcy's power over a woman was showed by his rejection to dance with Elizabeth who comes from middle class. He thinks that a man always concern with dignity, breeding, and gentility. While women today were as equal as men, women in the nineteenth century doesn't had the same opportunity. They had few rights, which contributed to rise of the women's rights and the suffrage movement thanks to which changed occurred in the course of the nineteenth century when they gained some rights with regard to marriage and voting. 


\section{b. Wealth}

Wealth refers to value of everything a person or family owns. This included tangible items such as jewelry, housing, cars, and other personal property. Financial assets such as stocks and bonds, which could be traded for cash, also contributed to wealth. Wealth was measured as "net assets," minus how much debt one owes. It also happened in theearlydecadesof the $19^{\text {th }}$ century, peopleinBritishsocietywereveryconcernedwithmoneyandclass. They attract their attention toward wealthy people to put them into upper class.

In this novel, there were described three major classes - upper, middle and lower. The upper class divided into three sections: the aristocracy, the gentry, and the squirarchy or class of independent gentlemen who doesn't had to work. Based on the novel, the majority of characters were described members of the upper class. The example of wealth was: Character: Mr.Bingley "Mr.Bingleywasgoodlookingandgentleman like;hehadapleasantcountenance, and easy,unaffected manners.Hissisterswerefinewomen,withanairofdecidedfashion.” Mr. Bingley was regarded as a gentleman. When he came to the neighbourhood, Bingley was instantly seen as a desirable potential husband of one of the Bennet daughters because of his wealth. Mr.Darcy also seen as a desirable potential husband because oh his had ten thousand a year. Having much money could be shaped someone in the wealth people. Money were the media through which characters must shape their lives. 


\section{c. Status}

Status means as position someone in the society. In this novel, woman's status was depended on their family and their marriage. That was why most woman dreams a man with good possession to be his wife. The example of Status was:

Character:

Mr.Bingley

“Itisatruthuniversallyacknowledged,thatasinglemaninpossessionofagoodfortune, mustbeinwantof awife." it was known that single man who came from rich family would be a dreaming for woman to be his wife because of their status. In the $18^{\text {th }}$ centuryperiod, woman status was placedgreatemphasisonmaninhissocialenvironment ratherthaninhisindividual conditions.Therefore they had to marry the most appropriate man that was sometimes even imposed on them by their family. Though they could choose whom they would marry, there was very little possibility that they would marry a man they loved, unless he was also wealthy and willing to marry her.

After grouping each dialogues and narration text containing social class based on the types, the representative of the data was presented in the table below:

Table 1 The numbers of the impacts of Social Class

\begin{tabular}{|c|c|c|}
\hline No. & Types of the social impacts & Numberofoccurences \\
\hline 1. & Pride & 10 \\
\hline 2. & Prejudice & 4 \\
\hline & Total & 14 \\
\hline
\end{tabular}


Table 2 The numbers of the Reflection of Social Class

\begin{tabular}{|r|c|c|}
\hline No. & $\begin{array}{c}\text { Types of how social class } \\
\text { reflected }\end{array}$ & $\begin{array}{c}\text { Number of } \\
\text { occurences }\end{array}$ \\
\hline 1. & Power & 9 \\
\hline 2. & Wealth & 9 \\
\hline 3. & Status & 13 \\
\hline & Total & 31 \\
\hline
\end{tabular}

Table 1 showed the total and pride was the dominant impact in social class toward british society in pride and prejudice novel. Table 2 showed the total and status was the dominant type of reflection of social class toward british society in Pride and Prejudice novel. Totally found 45 data, the data were seen in chapter 1 , $3,4,6,7,10,15,17,19,20,22,23,29,32,43,50,55,50$. There were two impacts of social class found in Pride and Prejudice novel, they were pride and prejudice and three types of social classes which were reflected, such as power, wealth, and status. 


\title{
CONCLUSIONS AND SUGGESTIONS
}

\author{
Conclusion
}

After analyzing the social class in Pride and Prejudice novel ,the conclusionswere drawn as the following:

1. There were two impacts of social class were found in Pride and Prejudice novel, they were pride and prejudice. Prideas feeling or deep pleasure or satisfaction derived from power's own achievement relatedmoretoouropinion ofourselves. Prejudice as feelings towards people or a person because of their social class.

2. There were three types of social classes reflected, in such as power, wealth, and status. Power the ability to influence others to believe, behave, or to value as those in desire them. Wealth refers to value of everything a person or family owns. Statusmeans as position someone in the society. In this novel, woman's status was depended on their family and their marriage.

\section{Suggestion}

Having seen the result of this research, it was useful to consider the following suggestions:

1. It was suggested that the readers prepare a selected novel and read it accurately to get a better understanding of the story in it. A selected novel 
was needed to offer the reader valuable messages or lesson particularly related to literature.

2. Other researchers were suggested to do further researches on drama, poetry, prose, etc, as a medium of studying literature. 


\section{REFERENCES}

Abrams, Lanita. 1980. From the Literary to Novel. New York: Oxford University Press.

Austen, Jane. 1972.Pride and Prejudice. Jakarta:PT. GramediaPustakaUtama.

Banhart, Gibbs. 2001. Literary Work. New York: Longman.

Baubusse, G and Glaymann, David. 2004. Social Stratification: Class, Race, and Gender in Sociological Perspective. 2nd ed. Boulder, Colo: Westview Press.

Dineen, J. 2002. Enjoying with Novel. Homewood: Dorsey Press.

Fathoni, A. 2015. Social Discrimination in Jane Austen's Sense and Sensibility (1811): A Marxist Approach. Publication Article. Journal of School of Teacher Training and Education Muhammadiyah University of Surakarta

Fraenkel, S and Wallen, A. 1993.Research : Qualitative Research.New York: Longman.

Fredeick, S. 2011. Habitus as thePrinciple forSocial Practice: A Proposal for Critical Discourse Analysis. Languagein society, Vol.32.143-175.

Freud, B. 2011.Social class inThe Routledge Companion to Sociolinguistics, ed. Carmen Llamas, Louise Mullany, and Peter Stockwell, 51-61. New York: Routledge.

Gie, A.2015.DeliveranceofSelf-RegardinJane Austen's 'Prideand Prejudice' Novel (1813):A PsychoanalyticApproach. Unpublished.Muhammadiyah Universityof Surakarta.

Gilbert, T and Kahl, M. 201 0.TheRoutledgeHistoryofLiteraturein English: 
Britain and Ireland.London: Routledge.

Hariyanti, M. 2014. Social Stratification Reflecteda at Jane Austen's PrideAndPrejudiceNovel(1813): A Sociological Approach. Umsu Surakarta Journal.

Kraus, M. 2012. SocialClass,Solipsism,AndContextualism: How TheRichAreDifferentFromThePoor. AmericanPsychologicalAssociation, Vol.119.546-572

Morina. 2013. AnAnalysis ofSocialClass and SocialStruggle in "TheHunger Games"MovieUsingMarxismTheory. Journal UniversitasBinaNusantara.

Rahayu, I. 2013. The Issue of Social Class in Chinua Achebe's Things Fall Apart. Educational Journal of English Department, Faculty of Letters, Jember University.

Saidin, P. 2013. Social Stratification and Classroom Discourse.London: Moughton.

Scout, R. 1980.Understanding the Literature. London: Mc Milan

Taylor, B.1981. Understanding the Element of Novel. New York: Longman

Taormine, M.L. 2009. Sociology:TheEssentials.California: Thomson Wadsworth.

Trace, L. 2005.TheTheoryoftheNovel. Massachusetts:TheMitPress.

Wellek,R andWarren, A.1977.Theory ofLiterature.NewYork: Harcourt.

Zahia, B. 2014.Social Classes Differences in Charles Dickens' Novel David Copperfield.Journal Academic Master. KasdiMerbah University. 